\title{
Abrus precatorius Poisoning: A Retrospective Study of 112 Patients
}

\author{
Aishwarya Karthikeyan, S. Deepak Amalnath \\ Department of Medicine, Jawaharlal Institute of Postgraduate Medical Education and Research, Puducherry, India
}

\section{Abstract}

Abrus precatorius is a rare but important cause of plant poisoning, especially in tropical countries like India. Most of the published literature on Abrus is limited a few case reports. Hence, we did a retrospective study the clinical features and outcome of Abrus poisoning. Case records of patients admitted to medicine wards during 7 years were included in the study. A total of 112 patients were studied. The majority were females (78\%), and most of the patients were between 13 and 30 years (81\%). Diarrhea was the most common symptom (66\%), and blood in stools was present in (33\%). Six patients had died with a mortality rate of $(5.35 \%)$.

Keywords: Abrus precatorius, case series, India, poisoning

\section{INTRODUCTION}

Abrus precatorius (known as kundumani in Tamil) is a poisonous plant which contains one of the most lethal toxin, Abrin, a toxalbumin that inhibits protein synthesis causing cell death. ${ }^{[1,2]}$ The seeds are crushed and taken orally for suicidal purpose. Most of the patients are from rural areas since this plant is predominantly seen in villages. There is no antidote for this poisoning.

Clinical features commonly include nausea, severe vomiting, diarrhea, abdominal pain, and gastrointestinal bleeding. ${ }^{[3,4]}$

Diarrhea can occur after 3-4 days of ingestion ${ }^{[5]}$ and can be profuse. This can cause death due to severe volume loss.

Other uncommon features include encephalopathy, arrhythmias, and renal failure due to volume depletion. ${ }^{[5,6]}$

A. precatorius is an uncommon cause of poisoning reported mainly from Southern parts of India, which is restricted only to individual case reports. ${ }^{[3,4,6-11]}$ Hence, this study was undertaken to document the clinical features and outcome of A. precatorius poisoning.

\section{Subjects and Methods}

This was a retrospective study of case records of patients (age $>13$ years) admitted to medicine wards over a period of 7 years (January 2009-December 2015). Institute Scientific

\begin{tabular}{|l|l|}
\hline \multicolumn{2}{|c|}{ Access this article online } \\
\hline Quick Response Code: & Website: \\
\hline & www.ijccm.org \\
\hline
\end{tabular}

Committee and Ethics Committee approvals were obtained. A pro forma was used to collect data regarding the age, sex, duration of hospital stay, number of seeds consumed, form of ingestion, symptoms, complications and the outcome.

\section{RESULTS}

We studied a total of 112 patients admitted due to A. precatorius poisoning. Most of the patients were females (78.7\%). Most of the patients (81\%) were between 13 and 30 years of age, with $41.6 \%$ between 13 and 20 years of age. The duration of hospital stay ranged from a single day to a maximum of 9 days, most of the with a stay duration of a single day $(44.25 \%)$. The most common form of ingestion was crushed seeds (58.40\%).

Majority of the patient presented with gastrointestinal symptoms $(72.57 \%)$ in the form of loose stools, vomiting, and pain abdomen [Table 1]. Bloody diarrhea was present in $29.4 \%$. Neurological involvement in the form altered sensorium, tremors, and seizures were present in 9 patients. Sixteen patients (14\%) did not have any features of toxicity.

Address for correspondence: Dr. S. Deepak Amalnath, Department of Medicine, Jawaharlal Institute of Postgraduate Medical Education and Research, Puducherry, India. E-mail: drdeepakmddm@yahoo.co.in

This is an open access article distributed under the terms of the Creative Commons Attribution-NonCommercial-ShareAlike 3.0 License, which allows others to remix, tweak, and build upon the work non-commercially, as long as the author is credited and the new creations are licensed under the identical terms.

For reprints contact: reprints@medknow.com

How to cite this article: Karthikeyan A, Amalnath SD. Abrus precatorius poisoning: A retrospective study of 112 patients. Indian J Crit Care Med 2017;21:224-5. 
Of the 112 patients, six patients expired [Table 2] and the rest recovered. All the six patients had taken a handful of crushed seeds and developed symptoms within $12 \mathrm{~h}$. All of them had profuse bloody diarrhea and autopsy showed congestion of the viscera, especially the lungs and intestines.

\section{Discussion}

A. precatorius contains Abrin one of the most lethal toxin with an estimated human lethal dose of $0.1-1 \mu \mathrm{g} / \mathrm{kg}$. Abrin is a ribosome inactivating protein which is similar to ricin, diphtheria toxin, and pseudomonas toxin. Abrin has two chains $-\mathrm{A}$ and $\mathrm{B}$. the $\mathrm{B}$ chain binds to $\beta$-D-galactopyranoside moieties on the cell surface and facilitates the entry of A chain. The A chain has RNA-N-glycosidase activity, causing depurination of adenine in the $28 \mathrm{~S}$ rRNA. This prevents the binding of elongation factor to the rRNA resulting in complete inhibition of RNA translation. ${ }^{[1,2]}$

The classical feature of Abrus toxicity is bloody diarrhea. Mechanisms of diarrhea have been attributed to increased capillary permeability (vascular leak syndrome), direct irritant

\begin{tabular}{lc}
\hline $\begin{array}{l}\text { Table 1: Signs and symptoms of Abrus precatorius } \\
\text { poisoning }\end{array}$ \\
\hline & Number of patients (\%) \\
\hline Gastrointestinal & $82(72.57)$ \\
Vomiting & $52(46.02)$ \\
Loose stools & $68(60.18)$ \\
Blood in stools & $33(29.20)$ \\
Abdominal pain & $8(7.08)$ \\
Fever & $4(3.54)$ \\
Neurological & $10(8.85)$ \\
Altered sensorium & $4(3.54)$ \\
Seizures & $4(3.54)$ \\
Tremors & $2(1.77)$ \\
Cardiovascular & $2(1.77)$ \\
Renal (decreased urine output) & $1(0.88)$ \\
Asymptomatic & $16(14.16)$ \\
\hline
\end{tabular}

\begin{tabular}{|c|c|c|c|}
\hline Age/sex & $\begin{array}{l}\text { Number of } \\
\text { seeds }\end{array}$ & $\begin{array}{l}\text { Time between intake } \\
\text { and death (days) }\end{array}$ & $\begin{array}{l}\text { Cause of } \\
\text { death }\end{array}$ \\
\hline 25/female & $\begin{array}{l}50 \text { crushed } \\
\text { seeds }\end{array}$ & 4 & $\begin{array}{l}\text { Pulmonary } \\
\text { edema }\end{array}$ \\
\hline $30 /$ female & $\begin{array}{l}\text { Handful } \\
\text { crushed seeds }\end{array}$ & 7 & $\begin{array}{l}\text { Refractory } \\
\text { shock }\end{array}$ \\
\hline $20 /$ female & $\begin{array}{l}20 \text { crushed } \\
\text { seeds }\end{array}$ & 7 & $\begin{array}{l}\text { Massive } \\
\text { hemoptysis }\end{array}$ \\
\hline $20 /$ female & $\begin{array}{l}\text { Handful } \\
\text { crushed seeds }\end{array}$ & 4 & $\begin{array}{l}\text { Diarrhea, } \\
\text { shock }\end{array}$ \\
\hline $30 /$ female & $\begin{array}{l}20 \text { crushed } \\
\text { seeds }\end{array}$ & 4 & $\begin{array}{l}\text { Diarrhea, } \\
\text { shock }\end{array}$ \\
\hline $46 /$ male & $\begin{array}{l}\text { Handful } \\
\text { crushed seeds }\end{array}$ & 2 & $\begin{array}{l}\text { Diarrhea, } \\
\text { shock }\end{array}$ \\
\hline
\end{tabular}

and denudation of intestinal mucosa. ${ }^{[12]}$ Endoscopy and colonoscopy show friable and ulcerated mucosa. ${ }^{[3,4]}$ Although diarrhea was present in $72.57 \%$ of our patients, only $29 \%$ had bloody stools. Diarrhea was often self-limiting and recovered with fluid support.

Neurological involvement is uncommon. These include encephalopathy, seizures, cortical thrombosis, and tremors. ${ }^{[6,7,9-11]}$ Nine patients had neurological involvement and magnetic resonance imaging brain done in one patient was normal.

All the six patients who died had taken crushed seeds. Autopsy showed congestion of the internal organs predominantly of the lungs, heart, and intestines.

\section{Limitations}

This was a retrospective study, and detailed histopathological analysis could not be carried out.

\section{Conclusion}

We report the largest series of Abrus poisoning with a mortality rate of $5.35 \%$. We hope that this study will be of use to physicians who care for these patients.

\section{Financial support and sponsorship}

Nil.

\section{Conflicts of interest}

There are no conflicts of interest.

\section{REFERENCES}

1. Gadadhar S, Karande AA. Abrin immunotoxin: Targeted cytotoxicity and intracellular trafficking pathway. PLoS One 2013;8:e58304.

2. Narayanan S, Surendranath K, Bora N, Surolia A, Karande AA. Ribosome inactivating proteins and apoptosis. FEBS Lett 2005;579:1324-31.

3. Khanra D, Talukdar A, Basu K, Mitra S. Abrus precatorius poisoning leading to hemorrhagic gastroduodenitis - A rare experience. J Forensic Toxicol Pharmacol 2014;3:1.

4. Ganesan R, Ettiyan R. Abrus precatorius induced hemorrhagic colitis. Am J Pharmacol Toxicol 2015;10:40-5.

5. Davies JH. Abrus precatorius (rosary pea). The most common lethal plant poison. J Fla Med Assoc 1978;65:188-91.

6. Patil MM, Patil SV, Akki AS, Lakhkar B, Badiger S. An arrow poison (Abrus precatorius) causing fatal poisoning in a child. J Clin Diagn Res 2016;10:SD03-4.

7. Sahoo R, Hamide A, Amalnath SD, Narayana BS. Acute demyelinating encephalitis due to Abrus precatorius poisoning - Complete recovery after steroid therapy. Clin Toxicol (Phila) 2008;46:1071-3.

8. Pillay VV, Bhagyanathan PV, Krishnaprasad R, Rajesh RR, Vishnupriya N. Poisoning due to white seed variety of Abrus precatorius. J Assoc Physicians India 2005;53:317-9.

9. Subrahmanyan D, Mathew J, Raj M. An unusual manifestation of Abrus precatorius poisoning: A report of two cases. Clin Toxicol (Phila) 2008;46:173-5.

10. Sahni V, Agarwal SK, Singh NP, Sikdar S. Acute demyelinating encephalitis after jequirity pea ingestion (Abrus precatorius). Clin Toxicol (Phila) 2007;45:77-9.

11. Vinod KV, Thabah MM, Venkatesh T, Thiruvikramaprakash G, Kumar SR, Dutta TK. A rare cause of dural venous sinus thrombosis. Neurol India 2013;61:669-70.

12. Dickers KJ, Bradberry SM, Rice P, Griffiths GD, Vale JA. Abrin poisoning. Toxicol Rev 2003;22:137-42. 